\title{
REITTEJÄ ON MONTA - TIETEELLISTEN KIRJASTOJEN KÄSITYKSIÄ TEKOÄLYSTÄ
}

STKS:n Uuden teknologian työryhmän jäsenet pohtivat syksyl-

lä 2021 pitämässään työpajassa kirjastojen tämänhetkisiä käsityksiä tekoälystä. Uusi ilmiö voi hämmentää, koska siihen liittyy monta eri näkökulmaa, monta roolia ja monta lähestymistapaa. Jostain kannattaa kuitenkin aloittaa ja kokeilemalla oppii. Tätä kautta kirjasto oppii paremmin tunnistamaan prosesseja, joita voi tekoälysovellutusten avulla kehittää.

"Tekoäly... Toivon, että se tekee kaiken tyhmän työn jonain päivänä, niin että kivat työt jää meille." Näin kuvasi tekoälyä yksi sтKs:n Uuden teknologian työryhmän jäsen elokuun työpajassa, jossa pohdittiin kirjastojen tämänhetkisiä käsityksiä tekoälystä. Tässä artikkelissa esitämme synteesin työpajasta ja siellä esitellyn kirjallisuuskatsauksen tuloksista.

Työpajan järjestivät Andrea Gasparini Oslon yliopiston kirjastosta ja Heli Kautonen Suomalaisen Kirjallisuuden Seuran kirjastosta. He esittelivät työpajan aluksi edellisenä vuonna tekemänsä ja pian julkaistavan kirjallisuuskatsauksensa (Gasparini \& Kautonen, 202I/2022). Tämän jälkeen työpajaan osallistuneet Uuden teknologian työryhmän jäsenet keskustelivat katsauksessa esiin nousseista teemoista: Miten tekoäly ymmärretään tieteellisissä kirjastoissa? Millaisia rooleja kirjastoilla tai kirjastoammattilaisilla voi ja tulisi olla suhteessa tekoälyyn? Mikä rooli on käyttäjillä, teknologialla itsellään tai suunnittelulla?

Työpajassa esitetyt näkemykset heijastavat samaa ajatusta, jota professori Teemu Roos korosti syksyn 202 I
Kirjastoverkkopäivillä: Tekoälyä ei voi eikä kannata määritellä tarkkaan. Yhdelle tekoäly tarkoittaa odotettua kirjastotyön tehostajaa, toiselle hiukan ärsyttävää hypetystermiä. Miksi siis ylipäätään puhua tekoälystä eikä mieluummin yksiselitteisesti ja tarkemmin määriteltävistä sovelluskohteista kuten suosittelupalveluista, kuvantunnistuksesta tai chattiboteista?

Andrean ja Helin kirjallisuuskatsaus osoitti, että tekoäly on käyttökelpoinen yleiskäsite, johon keskustelu uudesta teknologiasta on helppo kiinnittää. Kirjallisuuskatsausta varten tehtiin tiedonhaku laajalla käsitteellä ja se toi analysoitavaksi paljon lähteitä, joista pääosa oli tieteellisiä tutkimusartikkeleita, mutta joukossa oli myös kir-

\section{Role of library/librarians: Main findings}

Roles vary from neutral investigator $(6 / 88)$ or a dutiful professional learning to use new tools $(43 / 88)$, to a responsible guardian of free and unbiased knowledge ( $7 / 88)$, or even a agent of desirable change (12/88).

"Library can be seen as a valued partner and collaborator, instead of being seen solely as a service provider." (Burton et al. 2018)

"We must continue to find ways to make the machines work for us." (Arlitsch \& Newell 2017)

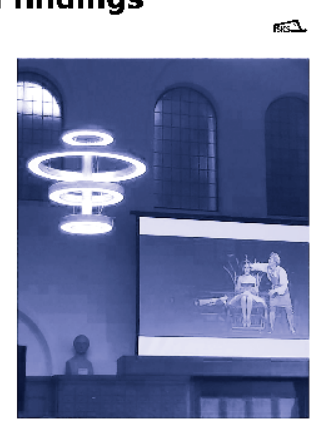


jastoalan ammattilaisille suunnattuja kannanottoja, uutisia ja projektiraportteja. Yli puolet (93/I 26) teksteistä oli julkaistu viimeisen kymmenen vuoden sisällä, mutta olipa joukossa varhainen kirjaston tekoälyvisio vuodelta 1976. Näin runsaasta aineistosta oli mahdollista piirtää kattava kokonaiskuva eri suuntiin polveilevista, uusia teknologioita koskevista toiveista, peloista, käytännön kokeiluista ja strategiapohdinnoista. (Gasparini \& Kautonen, 202 I/2022.)

\section{Kaikkien ei tarvitse olla koodareita}

Tekoälyn kaltaisen yleiskäsitteen käyttö jättää tilaa sille, että kirjastoissa voidaan lähestyä aihetta erilaisista rooleista käsin. Teknologiayritykset ja koodarit ovat toki ydinroolissa tekoälyn kehityksessä, mutta myös muiden alojen osaajien kannattaa ottaa asia omakseen. Tekoälyn ja algoritmien ymmärrystä voi tarvita myös tekoälyä hyödyntävien järjestelmien hankintapäätösten tekijä, käyttäjä tai käytön ohjaaja.

Kirjallisuuskatsauksen tulokset osoittavat, että tieteellisten kirjastojen kirjastoammattilaisille hahmotellaan aihetta käsittelevissä teksteissä erilaisia mahdollisia rooleja. Rooleja voi hahmottaa toisaalta suhteessa tekoälyyn ja toisaalta suhteessa muutokseen.

Suhteessa tekoälyyn, tulevaisuuden kirjastolaiset voidaan nähdä esimerkiksi ammattilaisina, jotka käyttävät tekoälyä hyödyntäviä työkaluja tai palveluja, tai ehkä jopa kehittävät niitä. Myös sitä pidetään mahdollisena, että kirjastolaiset kuuluvat ammattiryhmiin, jotka tulevat ainakin joiltain osin tekoälyn korvaamiksi. (Gasparini \& Kautonen, 202 I/2022.)

Skenaariot vaihtelevat sen suhteen, kuinka aktiivinen rooli kirjastoammattilaisille varataan. Tekoälyn kehittäjä on selvästi aktiivisempi toimija kuin palveluiden käyttäjä, puhumattakaan tilanteesta, jossa tekoäly korvaisi ammattilaiset. Myös vaadittavan teknologisen ymmärryksen taso vaihtelee eri rooleissa: palvelujen kehittäminen vaatii alan toimijoilta syvempää algoritmista osaamista kuin muut vaihtoehdot.

\section{Tarkkailijana vai muutosagenttina?}

Uuden teknologian työryhmän työpajassa tuli esiin erilaisia rooleja suhteessa muutokseen ja myös tässä asiassa kirjastoammattilaisten aktiivisuuden tasolle nähtiin eri vaihtoehtoja. Osaltaan pidettiin mahdollisena, että kirjastoammattilaiset tarkkailevat muutosta enemmänkin ulkopuolelta, mutta myös aktiivisempia rooleja muutosagenttina tai vähintäänkin muutokseen osallistujana pidettiin mahdollisena.

Kirjastoalan järjestöistä IFLA (2020, 2-3) on tehnyt suosituksia siitä, miten kirjastot voivat sopeuttaa palveluitaan tekoälyajan yhteiskunnallisiin tarpeisiin. IFLA pitää mahdollisena, että tekoäly voi merkittävästi vaikuttaa alan työmarkkinoihin ja toteaa, että erityyppiset kirjastot voivat kohdata vaikutukset eri tavoin. IFLA peräänkuuluttaa kirjastoalan järjestöjä tarjoamaan tukea kirjastoalan ammattilaisille uuden äärellä. IfLA näkee keskeisenä käyttäjien 
tukemisen tekoälyn ymmärtämisessä elinikäisen oppimisen hengessä ja sen varmistamisen, että kirjastojen käytössä olevat tekoälysovellukset ovat toimintatavoiltaan eettisiä ja turvaavat käyttäjien oikeuksia.

Viime aikoina on käynnistynyt keskustelu kirjastojen roolista tekoälylukutaidon tai algoritmisen lukutaidon levittämisessä. Algoritminen lukutaito pitää sisällään esimerkiksi perusymmärryksen algoritmeista, niiden käytön tunnistamisen, algoritmisten tekniikoiden soveltamisen sekä kyvyn arvioida algoritmien yhteiskunnallisia vaikutuksia ja vaikutusvaltaa. Nykyisellään esimerkiksi ACRL:n informaatiolukutaidon kehykset eivät riittävissä määrin sisällä näitä näkökulmia. (Ridley \& Pawlick-Potts 202 I, 4-8). Kanadassa ollaan tartuttu ajatukseen ja eri kirjastotahot ovat yhteistyössä käynnistämässä AI for all -projektia (aiforall. ca), jossa kehitetään yleisten kirjastojen kautta levitettävää algoritmilukutaidon koulutusta. Projektin etenemistä on kiinnostava seurata myös muista maista ja muilta kirjastosektoreilta käsin.

\section{Kokeilemalla oppii}

Isoja pohjoisamerikkalaisia yleisiä kirjastoja edustava Urban Libraries -järjestö on muutama vuosi sitten kasannut johtajille suunnatun muistion tekoälystä. Muistiossa hahmotellaan kirjastoille tekoälyn suhteen roolia, jossa yhdistyy ajatusjohtajuus, kirjastojen luotettavuus tiedon tarjoajana sekä demokratian ja oikeudenmukaisuuden edistäminen. (Urban Libraries 2019, 4.) Muistion keinot tavoitteeseen pää- semiseksi ovat osin melko yleisellä tasolla, mutta ne ovat hyvää ajateltavaa myös tieteellisille kirjastoille.

Kirjastoja suositellaan rakentamaan toimintaa vahvuuksiensa pohjalle ja keskittymään esimerkiksi digitaaliseen lukutaitoon ja osallistamiseen. Vastaavasti järjestö katsoo, että kirjastojen tulee puhtaan teknologian sijasta keskittyä siihen, miten tekoäly vaikuttaa kansalaisten elämään. Kirjastojen ei kannata yrittää olla asiantuntijoita kaikilla aloilla vaan luoda kumppanuuksia - tekoälyn kehittämistä ei kuitenkaan pitäisi jättää ainoastaan teknologiayritysten tehtäväksi. Keskeistä on ottaa henkilökunta mukaan. Tämän voi aloittaa esimerkiksi tarjoamalla mahdollisuuksia oppia uutta (Urban Libraries 20I9, 4).

Kirjastoalan sisäinen koulutustarjonta on lisääntynyt. Myös Suomessa on vuoden 202 I aikana järjestetty useita kirjastolaisille suunnattuja webinaareja tekoälystä ja uusista teknologioista. sTKs:n Uuden teknologian työryhmän webinaarien lisäksi yleisten kirjastojen alueellisen kehittämisen puitteissa on järjestetty useampikin koulutustapahtuma ja myös Kirjastoverkkopäivät tarttui aiheeseen. Lisäksi internetissä on paljon oppimateriaaleja tekoälystä ja koneoppimisesta, joten itsenäiseen oppimiseen on hyvät mahdollisuudet, kunhan vain löytää itselle sopivat sisällöt.

Kansainvälisen $\mathrm{AI}_{4} L A M$-verkoston (Artificial intelligence for libraries, archives and museums) koulutustyöryhmä on kartoittanut verkosta löytyviä kulttuurilaitoksille sopivia

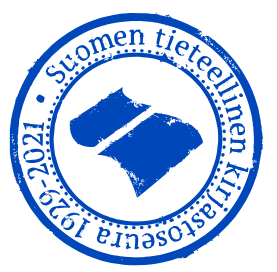


tekoälyyn liittyviä koulutusmateriaaleja. Kooste materiaaleista on tallennettu AI4LAMin verkkosivuille (sites. google.com/view/ai4lam/news/training-resources). Listalta löytyy niin Suomessa toteutettuja Elements of AI -verkkokursseja, webinaaritallenteita vaihtelevista aiheista ja Digital Humanities -tahojen tuottamia materiaaleja. Tarkoituksena oli tutkia materiaalien sopivuutta kulttuurilaitoksille ja saada selville, onko materiaalien sisällöissä aukkoja suhteessa GLAM-organisaatioiden tarpeisiin (AI4LAM 202 Ia, 2).

Ryhmän mukaan kirjastoissa, arkistoissa ja museoissa on tarpeen kehittää tekoälyyn liittyviä taitoja, sillä tämä parhaiten varmistaa sen, että teknologioita sovelletaan käyttöön sopivalla tavalla ja kriittisellä otteella sekä kulttuurialan kokoelmatyön haasteet huomioiden. Lisäksi ryhmä katsoo, että GLAM-sektorin asiantuntijoilla on laajemminkin yhteiskunnalle annettavaa esimerkiksi koneoppimisen eettisen käytön edistämisessä ja tekoälyn harjoitusdatan hallinnan tukemisessa. (AI4LAM 202 Ia, 2-4).

Työpajassamme keskustelimme siitä, miten parhaiten varmistaa, että omassa organisaatiossa on riittävästi osaamista uudenlaisten järjestelmien hankkimiseen tai kehittämiseen. Lisäksi pohdimme, miten osaamme tunnistaa tai opimme tunnistamaan prosesseja, joita voi tekoälysovellutusten avulla parantaa. Kirjastojen tekemät omat kokeilut ja niihin tutustuminen ovat tärkeitä myös tästä syystä.

\section{Kirjastot avainasemassa uusien teknologioiden haltuunotossa}

Tekoälystä käytävä keskustelu, kirjoitetut tutkimukset ja kannanotot - ja kieltämättä myös tämän artikkelin laatiminen - tuovat mieliimme edellisen digitalisaation tuoman ilmiön eli sen, miten internet ravisteli kirjastoammattilaisten arkea. Olemme uuden kirjastojen digiloikan lähtöviivalla, ja jotkut meistä jo lihaksiaan lämmittelemässä.

Kirjastojen asema tiedeyhteisöissä antaa oivallisen aseman, mutta myös velvollisuuden, tarttua tekoälyn tuomiin haasteisiin ja mahdollisuuksiin. Kirjastoammattilaisten vankka asiantuntemus tiedon saavutettavaksi tekemisestä, lähdekritiikistä, tiedon tuottamisen etiikasta ja nykyisistä digitaalisista välineistä luo hyvän pohjan tekoälyilmiön haltuunottoon.

Kirjastot ovat tiedeyhteisöissään sopivissa solmukohdissa: onhan kirjastoilla rajapinta niin käyttäjiin, opetukseen, tietohallintoon kuin yliopiston ulkopuolisiin tieteen ekosysteemien toimijoihin kuten kustantajiin. Kirjastoilla on hyppysissään myös tekoälyn kehittämiseen tarvittavaa lähtödataa (Kangas, 2020). Jotkut viittaavatkin tieteellisten kirjastojen merkitykseen tekoälyyn liittyvän tiedepolitiikan rakentajina (Henry, 2019).

Vuonna 2017 MIT:n kirjastonjohtaja Chris Bourg kannusti kirjastojen johtajia kohtaamaan pelottomasti tämän vaikealta tuntuvan uuden ilmiön. Viitaten moniin tekoälyä koskeviin riskeihin ja uhkiin, etenkin tieteellisen tiedon ja tutkimuksen näkökulmasta, 
hän kannustaa kirjastoja ottamaan roolia "demonien kesyttäjinä".

Kansallisia ja kansainvälisiä ammattilaisten ryhmiä seuraamalla näkee, että yhä useampi kirjasto valmistautuu tavalla tai toisella uuteen digiloikkaan. Kuten työpajamme ja siellä esitelty kirjallisuuskatsaus osoittivat, meillä on monta vaihtoehtoista polkua ottaa tekoälyä haltuun. Jokainen voi tehdä jotain ja aloittaa voi vaikka osallistumalla STKs:n Uuden teknologian työryhmän webinaareihin tai liittymällä ryhmän jäseneksi.

\section{Meidän kirjastossamme pitäisi olla strategia... tai joku käsitys siitä, miten tekoülyä voi hyödyntää. \\ (Työpajan osallistuja, 202 I.)}

\section{Lähteet}

AI4LAM. 202 Ia. AI training resources for GLAM - a snapshot - for public comment. October 202I. Saatavilla: https://docs.google.com/document/d/IFMoQVhfXPBj9y WYmkCLjrpvrLnQzKKjAXX6Fjo6Cndk/edit\# (I I. I I. 202 I)

BouRG, C., 2017. What happens to libraries and librarians when machines can read all the books? Saatavilla: https://chrisbourg.wordpress.com/2017/03/I6/what-happensto-libraries-and-librarians-when-machines-can-read-all-the-books/ (20.6. 2020)

Henry, G., 2019. Research Librarians as Guides and Navigators for AI Policies at Universities. Research Library Issues, 299, 47-66.

IFLA 2020., IFLA Statement on Libraries and Artificial Intelligence.

Saatavilla: https://www.ifla.org/wp-content/uploads/20I9/o5/assets/faife/ifla_ statement_on_libraries_and_artificial_intelligence.pdf (I I. I I. 202 I)

Kangas, P., 2020. Mikä on tekoälyn seuraava siirto? Kirjastolehti 29. 6. 2020.

Saatavilla: https://suomenkirjastoseura.fi/kirjastolehti/mika-on-tekoalyn-seuraavasiirto/ (I I. I I. 202 I)

Gasparini, A. \& Kautonen, H., [2021/2022]. Understanding Artificial Intelligence in Libraries. Liber Quarterly [vertaisarvioitavana].

Ridley, M. \& Pawlick-Potts, D., 202 I. Algorithmic Literacy and the Role for Libraries. Information technology and libraries. June $202 \mathrm{I}$.

Saatavilla: https://doi.org/ro.60I7/ital.v40i2.I 2963 (I I. I I. 202I)

Urban Libraries. 2019. AI Leadership Brief. Saatavilla: https://www.urbanlibraries. org/files/AI_Leadership-Brief.pdf (I 2. I I. 202 I)

Heli Kautonen

Suomalaisen Kirjallisuuden Seuran kirjasto heli.kautonen@finlit.fi
Pirjo Kangas

Ellibs Oy / Lingsoft Oy pirjo.kangas@gmail.com 